Vol.4, No.2, Oktober 2018

Doi: 10.24198/cosmogov.v2i2.xxxxx

\title{
BISNIS MILITER PASCA ORDE BARU
}

\author{
Nur Khairunisa Sugiarto ${ }^{1}$ \\ Ilmu Politik Fakultas Ilmu Sosial dan Ilmu Politik Universitas Padjadjaran \\ Email: khairunisa.sgrt@gmail.com
}

\begin{abstract}
ABSTRAK
Setelah jatuhnya rejim Suharto, keberadaan TNI sebagai sebuah kekuatan sosial politik digugat oleh banyak pihak. Mereka menganggap bahwa tidak seharusnya TNI menempati jabatan-jabatan di luar Hankam yang seharusnya menjadi porsi golongan sipil. Menurut Bilveer Singh, dalam kebanyakan masyarakat barat, peran militer pada dasarnya adalah untuk mendukung aspirasi politik masyarakat di bawah kepemimpinan sipil. Pernyataan ini didasarkan pada pendapat Samuel P. Hutington yang mengatakan bahwa mayoritas profesional militer di barat menerima kekuasaan sipil sebagai hak yang sudah semestinya ada. Oleh karena itu, ketika militer "menyimpang" dan ikut campur tangan dalam urusan sipil, maka sebagaimana dikatakan oleh Taufik Abdullah, muncul kekhawatiran yang didasarkan pada asumsi bahwa tindakan illegal telah dilakukan. Pemikiran yang menempatkan militer sebagai kekuatan yang mendukung sipil untuk menjalankan urusan yang menjadi "bagiannya" tidak sepenuhnya diterapkan di negara-negara dunia ketiga termasuk Indonesia. Kajian-kajian yang memperlihatkan intervensi militer dalam bidang politik menunjukkan bahwa kepentingan militer dan krisis yang dihadapi suatu negara mendorong militer ikut campur tangan dalam urusan sipil. Intervensi militer dalam bidang politik tidak dapat dipisahkan dengan penguasaan militer dalam bidang lain seperti bidang ekonomi.
\end{abstract}

Kata kunci: bisnis militer; orde baru; penguasaan sumberdaya

\begin{abstract}
After the fall of the Suharto regime, the TNI's existence as a socio-political force was sued by many parties. They assume that TNI should not occupy positions outside of Hankam that should be a portion of civilian groups. According to Bilveer Singh, in most western societies, the role of the military is essentially to support the political aspirations of society under civilian leadership. This statement is based on the opinion of Samuel P. Hutington who said that the majority of military professionals in the west accept civil power as a right that should exist. Therefore, when the military "deviates" and interferes in civil affairs, then, as Taufik Abdullah says, there is a concern based on the assumption that illegal acts have been committed. Thoughts that place the military as a civic-supporting force to carry out the affairs of its "part" are not fully applied in third world countries including Indonesia. Studies showing military intervention in politics show that military interests and the crisis facing a country push the military to interfere in civil affairs.
\end{abstract}


Vol.4, No.2, Oktober 2018

Doi: $10.24198 / \operatorname{cosmogov.v2i2.xxxxx}$

Military intervention in politics can not be separated from military control in other fields such as economics.

Keywords: military business; new order; resources controlling

\section{PENDAHULUAN}

Dari persfektif sejarah militer di Indonesia, kelahiran dan pembentukan militer Indonesia bukan merupakan bagian dari upaya yang dilakukan oleh kekuatan-kekuatan politik sipil. Akan tetapi, militer di Indonesia lahir secara langsung dari rahim revolusi. Meminjam ucapan Panglima Besar Jenderal Soedirman yang menyatakan: "Tentara dibentuk untuk membebaskan Indonesia dari ancaman imperialisme dan kolonialisme Belanda". Sebagai golongan rakyat yang dipersenjatai, pimpinan tentara saat itu berperan aktif bukan hanya untuk mempertahankan negara dari ancaman Belanda waktu agresi I dan II tahun 1948-1949, namun secara de facto ikut mengambil alih pemerintahan. Keikutsertaan tersebut berlanjut ketika negara menghadapi pemberontakan (subversi). Hal ini memperlihatkan militer Indonesia berada diposisi yang sejajar dengan politisi sipil atau bahkan dalam konteks "kesetiaan kepada negara" berada pada posisi yang lebih tinggi daripada otoritas politik sipil.

Upaya militer untuk dapat memperkuat dominasi terhadap negara menimbulkan gesekan dengan kekuatan-kekuatan sosial-politik lain, terutama pemerintahan sipil dan partai politik saat itu. Sehingga tidak mengherankan jika pada masa pemerintahan Soekarno, militer kerap terindikasi pembangkangan terhadap pemerintahan dan otoritas politik sipil. Adapun beberapa peristiwa penting yang menuju ke arah dominasi militer tersebut, diantaranya peristiwa penculikan Perdana Menteri Sjahrir yang diikuti dengan peristiwa 3 Juli 1946 di Yogyakarta, peristiwa demonstrasi oleh militer yang menuntut pembubaran parlemen pada 17 Oktober 1952, hingga pemboikotan pelantikan KSAD Kol. Bambang Utoyo pada 27 Juni 1955 oleh hampir seluruh perwira Angkatan Darat. Puncaknya penumpasan Gerakan G $30 \mathrm{~S}$ yang dituduhkan kepada PKI (Partai Komunis Indonesia).

Akibat suasana politik yang tegang itu, muncul keinginan militer untuk memperluas ruang lingkup kegiatannya guna memperkecil kemungkinan konflik antara elite politik sipil. Akhirnya militer saat itu, menawarkan pemikiran "jalan tengah" sebagai cikal bakal Dwi Fungsi ABRI melalui usulan A.H Nasution untuk mengakomodasi fungsi non-militer tentara demi menjaga wibawa dan keutuhan negara. Dan semakin menguat ketika berhasil terbentuknya Orde Baru untuk mengantikan rezim sebelumnya yang dinilai gagal menciptakan stabilitas politik dan pembangunan ekonomi.

Sejarah Bangsa Indonesia dan militer adalah dua hal yang sangat sulit 
Vol.4, No.2, Oktober 2018

Doi: $10.24198 / \operatorname{cosmogov.v2i2.xxxxx}$

dipisahkan. Karena dalam setiap momentum perjuangan kemerdekaan militer dan sipil adalah bagian yang satu dan saling bahu-membahu. Pada masa awal kemerdekaan stabilitas diantara keduanya selalu dijaga dengan baik, hingga sampai pada sebuah peristiwa besar dimana terjadinya peralihan kekuasaan dari Presiden Soekarno kepada Presiden Soeharto yang sangat kontrovesial. Sejak itupun istilah orde baru bergulir dibawah komando Presiden Soeharto, sebagai kelanjutan era Presiden Soekarno yang kemudian dikenal sebagai orde lama. Pada masa pemerintahan orde baru pembangunan terus bergulir, kepentingan politik dari dalam dan luar negeripun bermunculan, termasuk keinginan rezim yang berkuasa untuk terus melanggengkan kekuasaannya. Hal tersebut sontak menimbulkan pro-kontra dari berbagai kalangan di tanah air, gelombanggelombang protes terus bermunculan terhadap kebijkan-kebijakan pemerintah yang dianggap kontroversial dan otoriter, lalu hal tersebut direspon dengan sangat represif oleh pemerintah, sehingga tidak jarang menyebabkan korban jiwa baik secara terang-terangan maupun sembunyi-sembunyi.

Kekuasaan orde baru merupakan kekuasaan bergaya kepemimpinan militer, militer bahkan terstruktur dari daerah (Komando Teritorial) hingga parlemen, yang kemudian juga menempatkan ABRI sebagai salah satu fraksi di DPR. Militer menjadi mesin politik yang dominan dan kuat, bahkan kekuasaan militer juga tersistematis pada lembaga-lembaga negara secara umum, baik yang ada ditingkat pusat maupun daerah. Dominasi militer dalam pemerintahan negara kemudian menimbulkan gejolak yang luar biasa, dan gejolak tersebut meledak di tahun 1997-1998 yang menjadi puncak dari perlawanan sipil terhadap militer, peristiwa tersebut kita kenal dengan nama gerakan reformasi. Salah satu tuntutan reformasi adalah cabut Dwi Fungsi ABRI, artinya gelombang protes tersebut menginginkan ABRI angkat kaki dari panggung politik nasional dan fokus pada pertahanan dan keamanan negara. Hal tersebut dilakukan karena keikutsertaan militer dalam dunia politik dianggap membuat sistem demokrasi sulit untuk berkembang. Orde baru pun kemudian dinyatakan berakhir setelah secara resmi Presiden Soeharto menyatakan mengundurkan diri dari jabatannya.

Babak baru bernama reformasi dimulai, tuntutan reformasi menjadi sebuah amanat penting yang harus dijalankan oleh pemerintahan berikutnya. Pemerintahan yang dilanjutkan oleh Presiden Habibie juga mendapatkan tekanan dari berbagai kalangan untuk segera melakukan reformasi besar-besaran dalam pemerintahan, terutama terkait keberadaan prajurit militer dalam pemerintahan. Pro-kontra depolitisasi militer menjadi kontroversi yang tidak kunjung usai. Traumatik terhadap keterlibatan prajurit berbaju loreng dalam panggung politik seolah menjadi 
Vol.4, No.2, Oktober 2018

Doi: $10.24198 / \operatorname{cosmogov.v2i2.xxxxx}$

dendam masa lalu yang sulit dilupakan oleh masyarakat sipil. Akan tetapi seiring berjalannya era reformasi, pada tahun 2004 parlemen menjawab tuntutan pencabutan dwi fungsi ABRI yang digaung-gaungkan ketika menumbangkan rezim orde baru. Jawaban tersebut dituangkan dalam Undang-undang No. 34 tahun 2004 tentang Tentara Nasional Indonesia. Undang-undang tersebut mengatur tentang jatidiri, kedudukan, peran, fungsi, tugas, postur dan organisasi, pengerahan dan penggunaan kekuatan TNI, kewajiban dan larangan prajurit, pembiayaan, hubungan kelembagaan, dan ketentuan peralihan Tentara Nasional Indonesia. ${ }^{1}$ Akan tetapi undang-undang tersebut tidak menjawab secara jelas terkait keberadaan komando teritorial, sementara keberadaan komando teritorial kian menjadi perdebatan karena dianggap merupakan struktur militer yang secara aktif melakukan intervensi politik di daerah-daerah.

\section{Latar Belakang Perubahan Dominasi Politik Kepada Dominasi Ekonomi}

Kondisi krisis ekonomi yang berat dihadapi Indonesia ketika untuk pertama kalinya Soeharto berhasil menggantikan Soekarno dari kursi kepresidenan. Oleh karena itu, begitu Presiden Soeharto menjabat maka pilihan yang paling rasional adalah sesegera mungkin untuk memulai program-program ekonomi berkesinambungan. Program-program ekonomi tersebut kemudian ditetapkan dalam Tap. MPRS No. XXIII Tahun 1966 tentang "Pembaharuan Kebijaksanaan Landasan Ekonomi, Keuangan, Dan Pembangunan". Tap. MPRS No. XXIII Tahun 1966 tersebut merincikan tiga tahapan program ekonomi, yaitu:

1) Tahapan penyelamatan, yakni mencegah kemerosotan ekonomi agar tidak mejadi lebih buruk lagi.

2) Tahapan stabilisasi dan rehabilitasi ekonomi, yang mengendalikan inflasi dan memperbaiki infrastruktur ekonomi.

3) Tahap pembangunan ekonomi.

Oleh sebab itu, Orde Baru berusaha menciptakan negara yang militeristik bergaya kapitalis untuk mewujudkan perbaikan di bidang ekonomi. Dalam artian militer menjadi kelompok elite yang mendominasi seluruh dinamika kehidupan bernegara untuk melakukan akselerasi pembangunan (modal internasional menjadi amat penting bagi bertahanya mayarakat kapitalis Indonesia). Terdapat dua kondisi politik yang mendukung antara lain: berlangsungnya proses penyebaran militer ke dalam posisi-posisi kekuasaan birokrasi negara (populer disebut "penghijauan"). Serta berlangsung pengkonsolidasi dan sentralisasi kekuasaan militer (garis

\footnotetext{
${ }^{1}$ UU No. 34 Tahun 2004 tentang Tentara Nasional Indonesia
} 
Vol.4, No.2, Oktober 2018

Doi: $10.24198 /$ cosmogov.v2i2.xxxxx

komado) pada Mabes ABRI dan Departemen Pertahanan Dan Keamanan (HANKAM). Ibaratnya ABRI sedang mengepung semua jabatan strategis pemerintahan.

Namun, ABRI sendiri memiliki keterbatasan dalam menguasai bidang ekonomi, tetapi tetap saja menilai bidang ini amat penting untuk diamankan. Oleh sebab itu, ABRI memasuki dan mengkomandoi bidang ekonomi ini dengan bantuan dari kaumkaum teknokrat. Modus ekonomi ABRI tidak hanya terbatas pada usaha-usaha untuk mengakumulasi modal internasional, akan tetapi modus ini kemudian bertujuan untuk mempertahankan aset-aset ekonomi yang telah mereka kuasai. Dengan segala sumber daya potensial untuk hal tersebut ABRI mulai mendominasi aktifitas ekonomi di Indonesia melalui hukum besi oligarkhi (the iron law of oligarchy) dalam masyarakat.

Rabasa dan Haseman menulis bahwa terdapat pola keterlibatan ABRI dalam berbisnis dimana pola-pola tersebut menjadi ponompang struktur ekonomi ABRI. Selanjutnya dari pembentukan yayasan-yayasan ABRI, Rabasa dan Haseman menjelaskan bahwa upaya tersebut tidak lebih dari sekedar upaya penghidaran dari pajak dan juga merupakan langkah-langkah untuk menghindari aturan hukum yang membatasinya berbisnis.

Keberadaan militer di panggung bisnis di Indonesia yang sudah ada sejak jaman kemerdekaan Indonesia tahun 1945, dan mulai berkembang pada jaman Orde Lama di bawah pimpinan Soekarno, mulai menunjukkan sinar terangnya ketika Soekarno dengan cara yang tragis harus tersingkir dari kursi presidennya karena kasus tragedi G 30/ S yang memakan banyak korban di pihak militer. Pengganti Soekarno yaitu Soeharto melakukan kebijakan sapu bersih elemen elemen penting pendukung Bung Karno dengan cara pembantaian massal, pemenjaraan massal dan pembaharuan di bidang ekonomi besar besaran karena, sepeninggal Bung Karno, Republik Indonesia mengalamai krisis ekonomi yang cukup parah dengan banyaknya inflasi, dan hutang Indonesia yang menumpuk cukup banyak akibat adanya kekacauan politik pada tahun 1965.

Militer dalam hal ini ABRI mempunyai peran yang sangat besar dalam, penghancuran pemberontakan $\mathrm{G}$ 30/ $\mathrm{S}$ yang menurut versi Orde Baru di lakukan oleh PKI, pada jaman Orde Baru, militer dalam hal bisnis mengalami puncak keemasan, walaupun sebenarnya keterllibatan mereka tidak di perbolehkan, tetapi dengan perlindungan Soeharto hal ini menjadi hal yang lumrah dan biasa saja, masuknya militer pada bidang yang harusnya di kuasai oleh sipil ini seperti dalam hal birokrasi dan kebijakan yang di lakukan dalam pembangunan ekonomi di pemerintahan, menyebabkan militer mempunyai kontrol yang cukup besar pada bidang pemerintahan Soeharto, Beberapa perwira militer, atau kerabatnya, lantas 
Vol.4, No.2, Oktober 2018

Doi: $10.24198 / \operatorname{cosmogov.v2i2.xxxxx}$

berhasil melakukan ekspansi ekonomi dengan mengelola berbagai macam bidang usaha, dengan segenap kemudahan yang mereka peroleh. Hasilnya adalah luasnya jenjang keterlibatan dan dominasi mereka dalam bidang ekonomi, hingga lahirlah para kapitalis birokrat militer di Indonesia. Keuntungan lain dari posisi birokrasi adalah menjadikannya sebagai sarana untuk mempermudah usaha, atau mempermudah kerja sama dengan para pengusaha, baik pribumi dan terutama pihak asing dalam menjalankan aktivitas bisnis militer, para perwira militer tersebut banyak menduduki pos-pos strategis dalam perusahaan-perusahaan besar seperti jabatan direkutur atau pimpinan utama dalam perusahaan besar tersebut, bisnis yang di lakukan oleh militer juga melahirkan beberapa yayasan yang di kelola oleh militer dalam menjalankan bisnisnya.

Angkatan Darat merupakan elemen penting dalam pelaksanaan bisnis militer pada jaman Orde Baru, karena mungkin juga ini di pengaruhi oleh faktor bahwa Presiden RI pada saat itu adalah Pak Harto yang juga merupakan Jenderal Angkatan Darat. Contoh bahwa perwira militer $\mathrm{AD}$ menduduki jabatan penting adalah adanya kontrol ekspor minyak yang sangat penting dalam pendapatan negara di kuasai oleh perwira $A D$, Badan Logitik Nasional atau Bulog yang juga di kuasai oleh perwira AD.

Eksistensi militer dalam bisnis era Orde Barua juga di bantu dengan adanya doktrin atau paham tentang Dwi Fungsi ABRI yaitu ABRI menjadikan mereka berperan ganda selain menjadi kekuatan pertahanan dan keamanan mereka juga berkecimpung dalam bidang sosial- ekonomi dan sosial politik. Strategi ekonomi Orde Baru ialah mengarahkan pertumbuhan ekonomi yang maksimal dengan menggunakan modal asing dan teknologi asing secara besar-besaran. Dalam masalah pengelolaan modal asing dan modal dari Cina, kaum birokrat militer menggunakan kesempatan mengambil keuntungan, yaitu dengan memberikan konsesi, lisensi dan kontrak. Dengan menggunakan kekuasaan dan jabatan, birokrat militer menguasai pusat-pusat perdagangan, mereka mendapatkan bagian keuntungan dari modal asing dan Cina. Keuntungan dari modal asing dan modal Cina itu juga dipergunakan untuk memperkuat struktur kekuasaan birokrasi militer. Oleh karena itu ada simbiosis mutualisme antara modal asing dan modal Cina dengan birokrasi militer. Penguasa birokrasi militer selalu berusaha menciptakan stabilitas nasional, untuk menjamin keselamatan modal asing dan modal Cina. Sebaliknya pengusaha pemilik modal asing dan Cina memberikan keuntungan kepada para birokrat militer.

Hal itu di karenakan Presiden Soeharto di hadapkan pada masalah pelik setelah terjadinya perpindahan kekuasaan dari Soekarno dengan berpindah ketangannya, muncul adanya 
Vol.4, No.2, Oktober 2018

Doi: $10.24198 /$ cosmogov.v2i2.xxxxx

warisan hutang yang besar, dan pak Harto berusaha keras untuk melakukan pembaharuan dan pembangunan besar besaran dibidang ekonomi, dengan di bantu oleh anak anak buahnya yang juga berasal dari militer untuk menguasai beberapa pos penting dalam birokrasi dan juga mempunyai andil dalam kebijakan pembangunan ekonomi, tetapi karena militer Indonesia belum punyai kemampuan yang mumpuni dalam bidang ekonomi, maka dengan bantuan para teknokrat teknokrat sipil dan luar negeri dan dengan adanya investor asing yang menanamkan modalnya di Indonesia, maka munculah suatu kerja sama politik dan ekonomi yang menguntungkat kedua pihak dan melahirkan ekonomi kapitalis yang akhirnya membuat Indonesia menjadi negara ototerisme birokratik.

Gabungan kekuatan antara teknokrat asing dan pemodal asing menjdikan mereka mendapat keuntungan besar dalam bisnis mereka di Indonesia, dan ini juga karena militer melakukan perlindungan penuh terhadap kinerja mereka selama rezim Orde Baru berkuasa, superioritas militer atas sipil di masa Orde Baru ini membuat mereka seperti tidak ada hambatan dalam melakukan kebijakan ekonomi dan penguasaan terhadap birokrasi negara, karena mereka juga bermain dalam partai politik.

Keberhasilan pembangunan ekonomi dalam hal ini industrialisasi menurut Yahya Muhaimin ditentukan oleh faktor permodalan. Karena faktor- faktor permodalan hampir semua dikuasai oleh birokrat militer atau orang-orang yang mempunyai hubungan dekat dengan militer (termasuk pengusaha keturunan), yang memerlukan permodalan harus berurusan dengan birokrat-militer. Di arena inilah berlangsung pertarungan terselubung antara kelompokkelompok pengusaha klien pribumi tertentu dengan para pengusaha Cina peranakan yang mendasarkan strategi mereka pada pandangan keberhasilan bsinis mereka ditentukan kemampuan mereka memperoleh konsensi, kredit, dan lisensi. Termasuk dalam hal ini para pengusaha muda yang tergabung dalam HIPMI banyak memusatkan perhatian mereka pada upaya membina suatu persekutuan antara pejabat militer dengan pengusaha asli.

Sesungguhnya militer pada jaman Orde Baru memiliki peran ganda sebagai penguasa birokrasi/ pemerintahan sekaligus sebagai pelaku bisnis. Peran ganda ini tidak terlepas dari kepentingan politik untuk mempertahankan status quo otoritas militer pasca jatuhnya Orde Lama. Corak rezim Orde Baru yang otoriter tehnokratis di atas telah meletakkan struktur pemerintahan Orde Baru terletak pada dominasi militer dalam aspek kehidupan politik dan ekonomi yang dikelola secara otoriter dan memasang asas demokrasi. Walaupun rezim Orde Baru bukan rezim militer, akan tetapi otoriterisme birokratik telah menciptakan kuatnya otoritas negara dimana lembaga militer memegang 
Vol.4, No.2, Oktober 2018

Doi: $10.24198 /$ cosmogov.v2i2.xxxxx

kunci semua aspek politik, ekonomi, dan keamanan nasional. Berbagai kebijakan negara tak lebih hanya mencerminkan kepentingankepentingan ekonomi para pemegang kekuasaan. Artinya berbagai kondisi politik yang diterapkan oleh para penguasa militer dalam rezim otoriter mana pun di dunia tak bisa lepas dari tendensi politik ekonomi. Singkatnya terdapat paralelisme antara upaya penegakkan status quo politik dengan terpeliharanya status quo ekonomi.

\section{Dampak Bisnis Terhadap Profesionalisme Militer Indonesia}

Militer Indonesia yang mulai terjun ke dunia bisnis sejak era revolusi perjuangan kemerdekaan Indonesia ini sebenarnya di pengaruhi oleh doktrin Dwi Fungsi ABRI yang di cetuskan oleh Jenderal Nasution. Tugas utama militer adalah berperang membela kedaulatan negara dan menjaga keamanan serta menjaga stabilitas negara dari pihak pihak yang berusaha untuk mengganggu ke tiga hal tersebut, tetapi pada kenyataannya profesionalisme militer tersebut sering tidak tercapai karena militer lebih suka terjun kedunia bisnis yang lebih menjanjikan dalam menghadapi masa depan karena pendapatan mereka bisa lebih terjamin dari pada hanya mengurusi keamanan negara dan stabilitas dari ancaman makar, dll.

Sebenarnya tugas militer itu dalam arti sederhana adalah untuk mendukung kepentingan dan aspirasi masyarakat di bawah kepemimpinan sipil. Tetapi pada kenyatannya yang terjadi di Indonesia tidak seperti itu, militer yang terjun kedunia bisnis dan berorientasi komersial, dengan tujuan menambag pendapatan militer, kemudian lambat laun hal itu di salahgunakan untuk kepentingan pribadi para perwira tinggi militer Orde Baru, dengan mengadakan kerja sama dengan pengusaha Cina, dll, membuat mereka lebih betah dalam dunia bisnis daripada memimpin pasukan pasukan militer tersebut.

Selain itu, etos komersial dengan cepat menjalar ke luar lingkungan perwira-perwira yang langsung berurusan dengan kepemimpiunan dengan perusahaan-perusahaan angkatan bersanjata. Demikian pula kepada perwira yang diangkat untuk menduduki jabatan dalam birokrasi pemerintahan, lalu terlibat bersama rekan-rekan keturunan Cina dalam kegiatan-kegiatan perusahaan pribadi, baik atas nama pengusaha keturunan Cina maupun atas nama keluarganya. Sedangkan para panglima daerah militer tidak jarang memiliki sumber dana pribadi yang mereka dapatkan dari para pengusaha, khususnya keturunan Cina.

Dampak umum dari menurunnya profesionalisme militer akibat, militer terjun ke dunia bisnis adalah militer dalam hal ini TNI mendapat legistimasi dari rakyat karena berperan besar dalam pembangunan ekonomi, walaupun sebenarnya militer mendapat dana juga dari luar APBN, kerjasama antara pengusaha asing dengan perwira militer 
Vol.4, No.2, Oktober 2018

Doi: $10.24198 /$ cosmogov.v2i2.xxxxx

sebenarnya sangat merugikan rakyat kecil dan prajurit militer secara keseluruhan yang menimbulkan biaya ekonomi yang tinggi, banyak perwira militer lain yang sebenarnya iri dengan kerja sama militer dengan pengusaha tersebut, dan untuk mengurangi rasa tidak suka tersebut, mereka yang terjun kedunia bisnis kemudian membantu mereka yang terjun ke lapangan.

Dampak khusus dari orintasi komersial yang di lakukan militer yang paling signifikan adalah menurunnya profesionalisme militer dalam menjalankan tugas utamanya menjaga keamanan dan stabilitas negara, karena mereka lebih asyik dalam melakukan bisnis militer yang menggiurkan dari segi pendapatan, seperti mengelola BUMN, yayasan, koperasi, dll. Bisnis telah menggeser tugas pokok militer, yaitu menjaga keamanan dengan baik. Dari hal tersebut sudah membuktikan bahwa untuk menjadi militer yang profesional sangat sulit untuk mempertahankannya.

Karena hal tersebut diatas reformasin ekonomi, sosial politik di Indonesia sebenarnya sangat sulit di lakukan karena militer masih dengan bebas melakukan bisnis yang kapitalis hanya menguntungkan diri mereka pribadi dan melupakan kesejateraan prajuri di bawahnya dan masyarakat bawah, hal ini sebenarnya bisa di lakukan kalau Dwi Fungsi ABRI di hilangkan dan peran ABRI di kembalikan seperti semula yaitu menjaga stabilitas, keamanan dari berbagai ancaman makar dan lain lain.

\section{KESIMPULAN}

Militer pada Era Orde Baru mempunyai tempat yang sangat strategis dibanding golongan sipil. Karena militer sebagai tentara hasil didikan Belanda dan jepang, yang mahir dalam hal menguasai persenjataan, juga memiliki dukungan politik yang cukup untuk melaksanakan kekuasaan, selain itu karena faktor ekonomi yang menjadikan kaum militer berkecimpung dalam dunia bisnis yaitu karena pendapatan mereka yang kurang dalam memenuhi kebutuhan pribadi dan keluarganya dan juga kurang dalam pendapatan untuk mengembangkan militer di dalam negeri. Dan juga danya PP dari pemerintah yang membatasi PNS berkecimpung dalam bisnis swasta termasuk militer.

Hal itu juga di bantu dengan peralihan kekuasaan dari Presiden Soekarno ke tangan Presiden Soeharto yang merupakan orang militer, dengan berbagai kebijakannya dalam melakukan kebijakan pembangunan ekonomi yang strategis, perwira militer yang juga merupakan kaki tangannya dengan bebas melaksanakan bisnis militer yang sebenarnya sangat teralarang untuk di laksanakan dengan resiko di pecat dari jabatannya.

Bisnis yang di kelola oleh militer diantaranya yayasan, PT, koperasi dan kerja samanya dengan investor asing dan teknokrat sipil menyebabkan ekonomi Indonesia berkembang menjadi ekonomi kapitalis yang melahirkan negara ototerisme 
Vol.4, No.2, Oktober 2018

Doi: $10.24198 / \operatorname{cosmogov.v2i2.xxxxx}$

birokratis. Dengan bantuan militer dalam menjaga stabilitas tersebut membuat kapitalisme di Era Orde Baru mencapai puncak keemasan dan bisnis militer di Era Orde Baru mencapai kejayaannya.

Dengan doktrin Dwi Fungsi ABRI yang membuat rakyat Indonesia beranggapan bahwa militer juga peduli terhadap pembangunan ekonomi Indonesia membuat profesionalisme militer Indonesia mengalami penurunan, karena militer tidak lagi hanya sebagai tentara penjaga kemanan negara tetapi juga sebagai pelaku bisnis atau menjadi komisariat perusahaan perusahaan besar yang sangat penting bagi pembangunan negara.

\section{DAFTAR PUSTAKA}

Admodjo, Soetomo Sakijo. (2009). Optimalisasi Strategi Kompartementasi Wilayah Pertahanan pada KOREM 121/ABW, Kalimantan Barat. Jurnal Ketahanan Nasional. XIV (3): 15 .

Sujito, Arie. (2002). Gerakan Demiliterisasi di Era Transisi Demokrasi : Peta Masalah dan Pemanfaatan Peluang. Jurnal Ilmu Sosial dan Ilmu Politik. 6 (1): 123124.

Iswandi. (2000). Bisnis Militer Orde Baru. Bandung: PT Remaja Rosdakarya.

Diakronik: Jurnal Pemikiran dan Penelitian Sejarah, Jurusan Ilmu Sejarah FSSR UNS
Markas Besar. (2008). Buku Saku Netralitas TNI. Jakarta: TNI Mabes.

Said, Salim. (1987). The Political Role of the Indonesian Military: Past, Present and Future. Southeast Asian Journal of Social Science, Vol. 15, No.1.

Sundhaussen, Ulf. 1988. Politik Militer di Indonesia 1945-1967: Мenuju Dwi Fungsi ABRI. Jakarta : LP3ES. Yulianto, Dwi Pratomo. Militer dan Kekuasaan, Puncak-Puncak Krisis Hubungan Sipil-Militer di Indonesia. Yogyakarta: Narasi.

\section{Sumber Lain:}

Instruksi Panglima TNI Nomor: Ins/1/VIII/2008 tentang pedoman netralitas TNI dalam pemilu dan pilkada.

Makalah Farida Sarimaya. Kontroversi Komando Teritorial TNI. staf pengajar dijurusan pendidikan sejarah FPIPS Universitas Pendidikan Indonesia (UPI). 